\title{
JOURNAL.RU
}

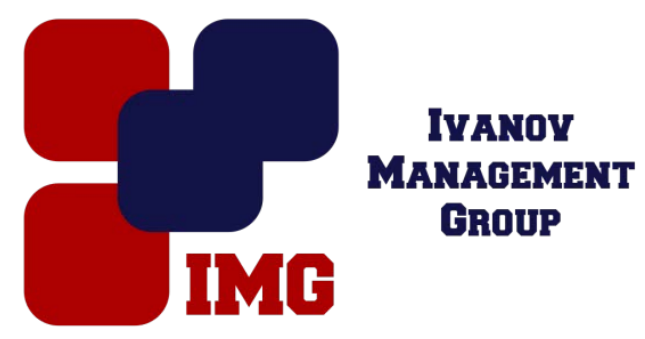

Герасимов К.Д., Вековцева Т.А. Южно-Уральский государственный университет Челябинск, Россия

doi: 10.18411/lj-31-01-2017-2-11

idsp 000001:lj-31-01-2017-2-11

\section{Event-маркетинг как средство формирования корпоративной культуры в высших учебных заведениях}

\section{Аннотация}

Современные тенденции развития сферы образования диктуют нам новые стандарты для высших учебных заведений, появляются новые задачи и требования, напрямую несвязанные с обучением.

Эта статья посвящена анализу менеджмента высших учебных заведений по средствам корпоративной культуры, включая в себя рассмотрение его особенностей и недочетов, а также предложения по их решению.

Ключевые слова: менеджмент, маркетинг, event-маркетинг, корпоративная культура.

Высшие учебные заведения играют важную роль в сфере образования, они имеют сложную структуру и очень специфичны. Как и любая сложная структура вузы нуждаются в хорошей организации и качественном менеджменте, обладают рядом особенностей.

Одной из главных таких особенностей является неоднородность участников внутренних коммуникаций. Такая среда подвержена высокой дифференциации и, как следствие, включает в себя большое количество рисков, базирующихся на стихийном формировании правил внутреннего взаимодействия, делая систему нестабильной [1].

Комплексный подходе и использование средств менеджмента позволяет не только уменьшить риски внутренних конфликтов, но и направить вектор развития коммуникаций в положительном направлении.Наиболее эффективным средством менеджмента для этого является корпоративная культура.

Анализируя устройство высших учебных заведений можно выделить три основные внутренние группы коммуникаций [5]: профессорскопреподавательский состав, сотрудники и служащий персонал, студент. В целом, формирование корпоративной культуры применяется повсеместно: создание 
внутриорганизационных уставов, внеучебная работа со студентами, профессиональные конференции профессорско-преподавательского состава.

Подобная практика несет в себе серьёзное упущение - укрепление корпоративной культурыпроисходить отдельно для каждого элемента и не направлено на установление партнерских взаимоотношений [3], как следствие не несет укрепления структуры в целом.

Решение данного недочета может быть достигнуто средствами проведение качественного event-маркетинга. Этот способ позволяет добиться долгосрочного эффекта, обхватить сразу всю структуру и является наиболее оптимальным в разрозненной среде.

Event-маркетинг - вид интегрированных маркетинговых коммуникаций, представляющий собой комплекс мероприятий, направленных на продвижение бренда во внутренней и/или внешней маркетинговой среде посредством организации специальных событий [2].

Особенностьюеvent-маркетинга является возможность установить крепкую эмоциональную связь, позволяет идентифицировать себя, относить к единой общности.

У event-маркетинга существует ряд ключевых особенностей, которые необходимо учитывать, к ним относятся: труднопредсказуемый результат, долгосрочная перспектива, длительный этап подготовки, необходимость системного подхода [4].

С учетом всех факторов можно сделать вывод, что использование eventмероприятий в настоящее время является одним из наиболее эффективных методов продвижения и средством достижения различных целей и задач.

В современной практике вузы регулярно проводят event-мероприятия различного уровня, условно эти мероприятия можно разделить на 2 категории: внутренние и внешние. К внутренним event-мероприятиям относятся различные олимпиады, досуговые, спортивные мероприятия и прочие. В большей степени эти мероприятия направлены на студенческую целевую аудиторию и как средства корпоративной культуры выполняют задачи по адаптации студентов в профессиональной среде и социализации в стенах вузов.

Вторая категория - внешние event-мероприятия - характеризуется цикличностью проведения. Направленные в первую очередь на поддержание и улучшение имиджа организации в глазах общественности. Отличаются длительными сроками подготовки, сложностью организации, необходимостью контроля на всех этапах организации. К ним относятся всемирные мероприятия и праздники: День знаний, Выпускной, Международный женский день, День защитника Отечества, День студента, День победы, и подобные.

Оценив календари мероприятий крупнейших вузов России, можносделать вывод, что политика вузов в проведении event-мероприятий несет скореe стихийный, чем систематический характер, из-за чего и эффект не несет долгосрочной перспективы. Такие единичные акции, без конкретного ряда задач могут пойти во вред, усложняя внутренние взаимоотношения [6]. 
C точки зрения менеджмента наиболее эффективными являются мероприятия, которые эмоционально связывают внутренние аудитории, позволяют себя идентифицировать как общую группу:флэш-мобы, спонтанные акции, идеи которых появились изнутри [1].Подобные мероприятий становятся традиционными и несут культурную-воспитательную функцию, поскольку изначально отображают, а после являются носителями ценностейвнутренней аудиторий. В основном, подобные культурно-традиционные мероприятиям рождаются и направлены на студенческую среду, в связи с социальной активностью данной целевой аудиторией, но бывают и обратные случаи, когда мероприятия охватывают сразу несколько внутренних аудиторий, иногда и внешнюю. Именно такие event-мероприятия способствуют формирования единой корпоративной культуры вуза.

На основе вышесказанного, авторы данной статьи придерживаются мнения, что качественный и систематически выстроенныйeventмаркетингпозволяет создать крепкую, принимаемую всеми внутренними контактными аудиториями, корпоративную культуру, неподверженную стихийным изменениям и с возможностью вертикального контроля.

\section{Литература}

1. Орлов А.И. Менеджмент. М.: Издательство «Изумруд», 2003. - 298 с.

2. Хальцбаур У. Event-менеджмент. М.: Издательство: «Эксмо», 2007. - 384 с.

3. Федотова М.Г. Коммуникационный менеджмент. Омск: Издательство:«ОмГТУ», 2006. $-76 \mathrm{c}$.

4. Котлер Ф. Основы маркетинга. М.: Издательскийдом «Вильяме», 2007. - 656 c.

5. Спивак В.А. Корпоративная культура: Теория и практика.Издательство: «Питер», 2001. $-352 \mathrm{c}$.

6. http://www.msu.ru/projects 